\begin{tabular}{|l|l|l||}
\hline \multicolumn{2}{|c|}{ PublisherInfo } \\
\hline \hline PublisherName & $:$ & BioMed Central \\
\hline \hline PublisherLocation & $:$ & London \\
\hline \hline PublisherImprintName & $:$ & BioMed Central \\
\hline \hline
\end{tabular}

\title{
Trauma-list discussion group
}

\begin{tabular}{|l|l|l||}
\hline \multicolumn{2}{|c|}{ ArticleInfo } \\
\hline \hline ArticleID & $:$ & 4273 \\
\hline \hline ArticleDOI & $:$ & $10.1186 /$ ccf-2000-webreport1080 \\
\hline \hline ArticleCitationID & $:$ & webreport1080 \\
\hline \hline ArticleSequenceNumber & $:$ & 14 \\
\hline \hline ArticleCategory & $:$ & Web report \\
\hline \hline ArticleFirstPage & $:$ & 1 \\
\hline \hline ArticleLastPage & $:$ & 3 \\
\hline \hline & & RegistrationDate : 2000-1-28 \\
\hline ArticleHistory & $:$ & OnlineDate \\
\hline \hline ArticleCopyright & $:$ & Current Science Ltd2000-1-28 \\
\hline \hline ArticleGrants & $:$ & \\
\hline \hline ArticleContext & $:$ & 1305444 \\
\hline \hline
\end{tabular}




\section{Overview}

TRAUMA.ORG provides a free forum for all healthcare professionals involved in trauma care. The trauma-list discussion section allows members to post and receive messages relating to critical care. The list also claims to be used to post details of forthcoming events, and in the future aims to contain original articles and papers relating to the field of trauma care.

\section{Content}

With 900 members this is a good opportunity for healthcare professionals to get feedback on queries or ideas. Many of the issues raised by members had more than 20 responses, with debate continuing for weeks. However, it is noticeable that many of the responses come from the same small percentage of people. Instructions on how to submit queries are clear, and the layout makes it easy to find your way around. There is no search facility for this part of TRAUMA.ORG, but the debates are all organised under umbrella headings, making it simple to find the topic you are interested in.

\section{Other comments}

The site is continually updated.

\section{Evaluation}

Registration is free. 


\section{References}

1. TRAUMA.ORG. [http://www.trauma.org/traumalist.html]

This PDF file was created after publication. 